\title{
PENGGUNAAN MEDIA SOSIAL DENGAN PENDEKATAN MODEL AIDA BAGI ROTI BUND DALAM MENINGKATKAN MINAT BELI KONSUMEN
}

\author{
USE OF SOCIAL MEDIA WITH AIDA MODEL APPROACH TO ROTI BUND IN \\ IMPROVING CONSUMER BUYING INTEREST
}

\author{
Bunga Ega Evania*, Roni Kastaman, Totok Pujianto
}

\author{
Universitas Padjadjaran, Jl. Raya Bandung-Sumedang KM 21 Jatinangor, Jawa Barat: 45363 \\ *E-mail: roni.kastaman@unpad.ac.id
}

(Diterima 29-07-2021; Disetujui 15-12-2021)

\begin{abstract}
ABSTRAK
Salah satu teknologi internet yang sedang berkembang pesat yang sangat berpotensi untuk mendorong pemasaran usaha kecil menengah adalah media sosial. Roti Bund harus meningkatkan strategi pemasaran memanfaatkan media sosial sehingga menarik minat beli konsumen. Penelitian ini bertujuan untuk mengetahui apakah ada pengaruh positif dan signifikan antara Strategi Pemasaran Melalui Media Sosial "Instagram" Dalam Meningkatkan Minat Beli Konsumen Roti Bund, dan mengaplikasikan penggunaan media sosial dengan mengacu pada Model AIDA bagi Roti Bund. Penggunaan Model AIDA digunakan untuk membantu Roti Bund dalam memaksimalkan penggunaan media sosial, sehingga Roti Bund mampu lebih optimal memasarkan produk/jasa melalui media sosial. Hasil penelitian menunjukkan bahwa 59,6\% minat beli konsumen benar-benar dikarenakan faktor attention, interest, desire dan action. Variabel attention berpengaruh paling dominan terhadap peningkatan minat beli konsumen. jadi pada penggunaan instagram yang harus dioptimalkan adalah pada variabel attention terlebih dahulu yaitu adalah postingan produk yang diposting harus menggunakan visualisasi yang berkualitas, jujur dan bisa diandalkan dalam penggunaan gambar dan captionnya dan harus memiliki keunikan yang membedakan postingan roti bund dengan postingan perusahaan lain, caption juga harus mampu membangkitkan keinginan untuk mengetahui lebih dalam mengenai produk tersebut contohnya dengan menjelaskan manfaat produk.
\end{abstract}

Kata kunci: media social, AIDA, Instagram, minat beli konsumen

\section{ABSTRACT}

The internet offers many benefits for small and medium businesses to increase the marketing of their products. One of the rapidly developing internet technologies that have the potential to encourage small and medium business marketing is social media. Roti Bund must improve its marketing strategy using social media so that it attracts consumer buying interest. This study aims to determine whether there is a positive and significant influence between the Marketing Strategy through Social Media "Instagram" in Increasing Consumer Purchase Interest of Bund Bread and applying the use of social media by referring to the AIDA Model for Roti Bund. The use of the AIDA Model is used to assist Roti Bund in maximizing the use of social media, so that Roti Bund is able to more optimally market products / services through social media. The results showed that $59.6 \%$ of consumers' buying interest was really due to the factors of attention, interest, desire and action. variable attention has the most dominant effect on the increase in consumer buying interest. So in the use of Instagram that must be optimized is the attention variable first, that is, product posts that are posted must use quality, honest and reliable visualization in the use of images and captions and must have uniqueness that differentiates bakery bund posts from other companies' posts, captions as well. must be able to arouse the desire to know more about the product for example by explaining the benefits of the product.

Keywords: social media, AIDA, Instagram, consumer buying interest 


\section{PENGGUNAAN MEDIA SOSIAL DENGAN PENDEKATAN MODEL AIDA BAGI ROTI BUND \\ DALAM MENINGKATKAN MINAT BELI KONSUMEN \\ Bunga Ega Evania, Roni Kastaman, dan Totok Pujianto}

\section{PENDAHULUAN}

Media sosial adalah sebuah media di internet yang memungkinkan pengguna tidak hanya mengekspresikan diri, tetapi juga berinteraksi, berkolaborasi, berbagi, berkomunikasi, dan bersosialisasi dengan pengguna lain. Kemunculan situs jejaring sosial ini dimulai sebagai inisiatif untuk menghubungkan orang-orang di seluruh dunia. Media sosial yang paling sering digunakan untuk promosi adalah Instagram.

Instagram dan Facebook adalah media sosial yang paling banyak digunakan untuk usaha kecil menengah. Media sosial ini banyak digunakan oleh pelaku usaha untuk berbagi konten promosi produk guna menarik minat konsumen. Dengan Instagram, pelaku usaha dapat menjangkau pasar anak muda usia produktif. ((Purwidiantoro et al, 2016))

Roti Bund adalah perusahaan yang bergerak dalam kategori industri makanan yang menghasilkan beberapa produk olahan roti yang berada di Buah Batu Regensi F3 No.16 Kota Bandung. Roti Bund mulai melakukan produksi pada tahun 2020. Perkembangan teknologi ini, memungkinkan Roti Bund untuk menjual dan mempromosikan produk atau jasa mereka sehingga mampu meningkatkan penjualan produk mereka. Berbagai produk Roti Bund sudah dipasarkan ke media sosial seperti Instagram. Roti Bund memiliki akun official Instagram yaitu@rotibund yang melakukan postingan pertama produknya pada bulan Mei 2020 yang telah memiliki followers lebih dari 2600. Roti Bund mempromosikan produk dengan mengiklankan foto, video dan review dari konsumen.

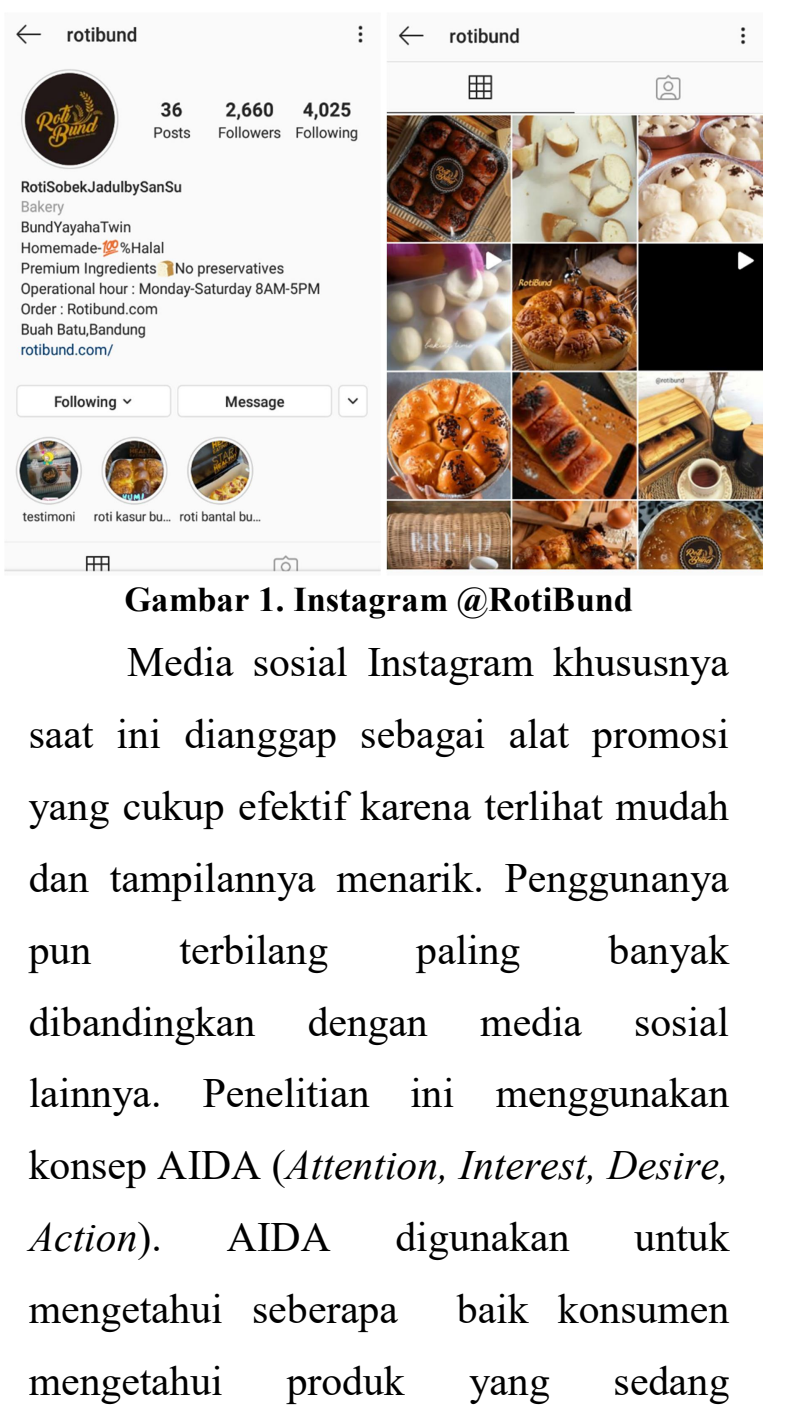


dipasarkan pada media sosial instagram dan apakah dengan pemasaran tersebut mereka melakukan action untuk membeli. Konsep AIDA dimulai dengan tahap menaruh perhatian (attention) terhadap produk atau layanan yang kemudian jika terkesan dia akan melangkah ketahap ketertarikan (interest) untuk mengetahui lebih jauh tentang keistimewaan produk atau layanan tersebut dan jika intensitas ketertarikannya kuat maka akan berlanjut ke tahap hasrat atau berminat (desire) karena barang atau jasa yang ditawarkan sesuai permintaan, jika hasrat dan minatnya begitu kuat maka konsumen akan ke tahap (action) dimana calon pembeli memutuskan pembelian.

\section{METODE PENELITIAN}

Penelitian ini dilakukan pada bulan desember 2020 hingga februari 2021 berlokasi di Roti Bund Buah Batu Regency No.16. Kegiatan penelitian ini akan dilakukan dengan model AIDA yang bertujuan untuk mengetahui penggunaan media sosial yang tepat dengan pendekatan model AIDA bagi Roti Bund. Langkah-langkah yang peneliti lakukan adalah observasi dan wawancara yang dilakukan untuk memperoleh keterangan mengenai pendapat pemilik Roti Bund mengenai media sosial Instagram Roti Bund dan kendala yang dihadapi dalam pemasaran yang dilakukan di media sosial Instagram, langkah selanjutnya adalah penyebaran kuisioner yang dilakukan untuk mendapatkan penilaian konsumen mengenai media sosial Roti Bund berdasarkan AIDA dan langkah yang terakhir adalah studi kepustakaan yang dilakukan untuk mendapatkan informasi mengenai pemasaran dalam media sosial instagram. Peneliti memperoleh data mengenai kendala yang dihadapi oleh Roti Bund dalam pemasaran pada media sosial instagram yang dilakukan dan pendapat konsumen mengenai media sosial instagram yang dilakukan oleh Roti Bund, selanjutnya peneliti mengolah data kuisioner dan melakukan analisa kepada pendapat konsumen mengenai media sosial Roti Bund dan membuat usulan perbaikan sesuai dengan pendapat konsumen untuk meningkatkan penggunaan media sosial instagram Roti Bund.

Penelitian ini menggunakan empat variabel bebas dan satu variabel terikat. Variabel bebas adalah variabel yang mempengaruhi atau menyebabkan terjadinya variabel terikat dan variabel terikat adalah variabel yang dipengaruhi 
oleh variabel bebas (Sugiyono, 2010).

Dalam penelitian ini yang menjadi variabel bebasnya adalah AIDA yang meliputi, Attention $\left(\mathrm{X}_{1}\right)$, Interest $\left(\mathrm{X}_{2}\right)$, Desire $\left(\mathrm{X}_{3}\right)$ dan Action $\left(\mathrm{X}_{4}\right)$, sedangkan variabel terikat pada penelitian ini yaitu Minat Beli Konsumen (Y). Berikut indikator-indikator yang digunkan untuk mengukur setiap variabel:

Tabel 1. Variabel dan Indikator Penelitian

\begin{tabular}{|c|c|}
\hline Variabel & Indikator \\
\hline $\begin{array}{c}\text { Attention } \\
\mathrm{X}_{1}\end{array}$ & $\begin{array}{l}\text { 1. Pesan yang disampaikan } \\
\text { dalam postingan } \\
\text { 2. Kepercayaan terhadap produk } \\
\text { 3. Visualisasi/penampilan yang } \\
\text { menarik }\end{array}$ \\
\hline $\begin{array}{c}\text { Interest } \\
\mathrm{X}_{2}\end{array}$ & $\begin{array}{ll}\text { 1. } & \begin{array}{l}\text { Efektivitas media yang } \\
\text { digunakan }\end{array} \\
\text { 2. } & \text { Persepsi konsumen mengenai } \\
\text { produk setelah melihat media } \\
\text { sosial Roti Bund }\end{array}$ \\
\hline $\begin{array}{c}\text { Desire } \\
\mathrm{X}_{3}\end{array}$ & $\begin{array}{ll}\text { 1. Informasi mengenai } \\
\text { keunggulan produk } \\
\text { 2. Postingan membangkitkan } \\
\text { keinginan untuk } \\
\text { mengkonsumsi produk } \\
\text { 3. Postingan menampilkan alasan } \\
\text { mengkonsumsi }\end{array}$ \\
\hline $\begin{array}{c}\text { Action } \\
\mathrm{X}_{4}\end{array}$ & $\begin{array}{l}\text { 1. Keyakinan untuk membeli } \\
\text { Produk } \\
\text { 2. Caption menggunakan kata- } \\
\text { kata yang sopan dan elegan } \\
\text { 3. Postingan yang menarik }\end{array}$ \\
\hline
\end{tabular}

\section{Teknik Analisis Data}

1. Pengujian Validitas

Validitas menurut (Sugiyono, 2016) mengacu pada tingkat keakuratan antara data yang benar-benar terjadi pada subjek dan data yang dikumpulkan oleh peneliti untuk mencari validitas sebuah item, kita mengkorelasikan skor item dengan total item-item tersebut. Koefisien antara item dengan total item sama atau di atas 0,3 maka item tersebut dinyatakan valid, tetapi jika nilai korelasinya di bawah 0,3 maka item tersebut dinyatakan tidak valid, untuk mencari nilai koefisien, peneliti menggunakan rumus pearson product moment.

Persyaratan minimum untuk dianggap suatu butir instrument valid adalah nilai indeks valid adalah nilai indeks validitasnya $\geq 0,3$ (Sugiyono, 2016) oleh karena itu, semua pernyataan dengan tingkat korelasi di bawah 0,3 harus diperbaiki karena dianggap tidak valid. (Kementrian Perindustrian, 2019)

2. Uji Reliabilitas

Uji reliabilitas adalah pengukuran dengan menggunakan objek yang sama sudah cukup untuk menghasilkan data yang sama (Sugiyono, 2012). Uji realianilitas kuesioner dalam penelitian menggunakan metode split half item tersebut dibagi menjadi dua kelompok yaitu kelompok ganjil dan kelompok genap. jumlahkan skor setiap kelompok untuk setiap item untuk membuat skor total apabila korelasi 0,7 maka dikatakan item tersebut memberikan tingkat reliabel yang cukup, sebaliknya apabila nilai korelasi di bawah 0,7 maka dikatakan item tersebut kurang reliabel. Adapun 
rumus untuk mencari reliabilitas adalah dengan mencari koefesien korelasi.

Setelah koefisien korelasi diketahui, maka selanjutnya hasil tersebut dimasukan ke dalam rumus Spearman Brown.

\section{Uji Regresi Linier Berganda}

Digunakan untuk mengetahui besarnya pengaruh variable independen terhadap variable dependen (Djarwanto \& Pangestu, 1998). Uji ini digunakan untuk menguji pengaruh variable independen (Media sosial Roti Bund dengan model AIDA (Attention, Interest, Desire, Action) terhadap variable dependen (minat beli konsumen).

Persamaan regresi tersebut dapat digambarkan sebagai berikut :

$$
\mathrm{Y}=\mathrm{a}+\mathrm{b}_{1} \mathrm{X}_{1}+\mathrm{b}_{2} \mathrm{X}_{2}+\mathrm{b}_{3} \mathrm{X}_{3}+\mathrm{b}_{4} \mathrm{X}_{4}
$$

dimana :

$\mathrm{Y} \quad=$ Variabel minat beli konsumen

$\mathrm{X}_{1} \quad=\quad$ Variabel model Attention (perhatian)

$\mathrm{X}_{2} \quad=$ Variabel model Interest (ketertarikan)

$\mathrm{X}_{3} \quad=$ Variabel model Desire (keinginan)

$\mathrm{X}_{4} \quad$ Variabel model Action (tindakan)

a $\quad=$ konstanta

$\mathrm{b}_{1}, \mathrm{~b}_{2}, \mathrm{~b}_{3}, \mathrm{~b}_{4}=$ koefisien regresi

(Djarwanto \& Pangestu, 1998)

4. Uji t (Uji Hipotesis Parsial)

Uji $\mathrm{t}$ bertujuan untuk mengetahui besarnya pengaruh masing-masing variable independen secara parsial terhadap variable dependen (Nugroho, 2005). Langkah-langkan pengujian :

a) menentukan formulasi hipotesis nihil dan hipotesis alternatif Ho: bi $=0$, artinya tidak ada pengaruh yang signifikan secara parsial variable independen terhadap variable dependen. Ha: bi $\neq 0$, artinya ada pengaruh yang signifikan secara parsial variable independen terhadap variable dependen.

b) menggunakan taraf signifikansi $(\alpha)=$ 0.05

c) mencari t hitung dengan rumus :

t hitung $=$ bi $/$ Sbi

dimana :

th $=$ Harga statistik $\mathrm{t}$

bi $=$ koefisien regresi masingmasing variabel

Sbi $=$ Standar error koefisien regresi masing-masing variabel

d) kriteria pengujian

Ho diterima bila : probabilitas > 0,05 (karena $\alpha$ yang digunakan adalah $5 \%$ artinya secara parsial variabel independen tidak berpengaruh terhadap variabel dependen minat beli.

Ho ditolak bila : probabilitas $\leq 0,05$ artinya secara parsial variabel independen berpengaruh terhadap variabel dependen minat beli. 
e) kesimpulan

Pengambilan kesimpulan dengan membandingkan antara nilai probabilitas dengan nilai signifikansi dari $\alpha$.

5. Uji F (pengujian secara serempak)

Uji $F$ bertujuan untuk mengetahui besarnya pengaruh bersamasama variable independen terhadap variable dependen (Nugroho, 2005). Langkah-langkah pengujian :

a) menentukan formulasi hipotesis nihil dan hipotesis alternatif

Ho: $b_{1}=b_{2}=b_{3}=b_{4}=0$, artinya tidak ada pengaruh yang signifikan secara bersama-sama variable independen terhadap variable dependen.

Ha: $b_{1}=b_{2}=b_{3}=b_{4} \neq 0$, artinya ada pengaruh yang signifikan secara bersama-sama variable independen terhadap variable dependen.

b) menggunakan taraf signifikansi $(\square)=$ 0.05

c) mencari $\mathrm{F}$ hitung dengan rumus :

$\mathrm{F}$ hitung $=\left(\mathrm{R}^{2} /(\mathrm{k}-1)\right) /\left(\left(1-\mathrm{R}^{2}\right) /(\mathrm{n}-\mathrm{k})\right)$ dimana :

$\mathrm{R}^{2}=$ Koefisien determinasi

$\mathrm{k}=\mathrm{Jumlah}$ variabel independen

$\mathrm{n}=$ Jumlah data dalam variabel

d) kriteria pengujian

Ho diterima bila : probabilitas > 0,05 (karena $\alpha$ yang digunakan adalah $5 \%$ ) artinya variabel independen (iklan dengan model Attention, Interest, Desire, Action) tidak berpengaruh terhadap variabel dependen minat beli.

Ho ditolak bila : probabilitas $\leq 0,05$ artinya variabel independen (iklan dengan model Attention, Interest, Desire, Action) berpengaruh terhadap variabel dependen minat beli.

e) kesimpulan

Pengambilan kesimpulan dengan membandingkan antara nilai probabilitas dengan nilai signifikansi dari $\alpha$.

6. Uji Korelasi Determinasi $\left(\mathrm{R}^{2}\right)$

Pengujian ini dimaksudkan untuk mengetahui seberapa besar pengaruh dari seluruh variabel independen yang ada dan besarnya pengaruh yang disebabkan oleh variabel lain yang tidak dapat dijelaskan. Hal ini ditunjukkan oleh besarnya koefisien determinan $\left(\mathrm{R}^{2}\right)$ yang besarnya antara 0 sampai 1 atau $0 \leq \mathrm{R}^{2} \leq 1$. Jika $\mathrm{R}^{2}$ mendekati 1 maka varaibel independen berpengaruh terhadap variabel dependen dengan sempurna atau terdapat suatu kecocokan yang sempurna (variabel independen yang dipakai dapat menerangkan dengan baik variabel dependen). Namun jika koefisien determinasi adalah nol (0) berarti variabel independen tidak berpengaruh terhadap variabel dependen. 
Peneliti menggunakan alat bantu SPSS dalam mengolah dan menganalisis regresi independen terhadap variabel dependen.

\section{HASIL DAN PEMBAHASAN}

Hasil validitas setiap item pertanyaan dalam variabel dapat dilihat pada Tabel 2.

Tabel 2. Hasil Uji Validitas

\begin{tabular}{lcccc}
\hline Variabel & $\begin{array}{c}\text { Item } \\
\text { Pertanya- } \\
\text { an }\end{array}$ & $\mathrm{R}_{\text {Tabel }}$ & $\mathrm{R}_{\text {hitung }}$ & $\begin{array}{c}\text { Kete- } \\
\text { rangan }\end{array}$ \\
\hline \multirow{5}{*}{ Attention } & $\mathrm{A}_{1}$ & 0,195 & 0,634 & Valid \\
& $\mathrm{A}_{2}$ & 0,195 & 0,623 & Valid \\
& $\mathrm{A}_{3}$ & 0,195 & 0,643 & Valid \\
& $\mathrm{A}_{4}$ & 0,195 & 0,446 & Valid \\
& $\mathrm{A}_{5}$ & 0,195 & 0,664 & Valid \\
\hline \multirow{5}{*}{ Interest } & $\mathrm{I}_{1}$ & 0,195 & 0,441 & Valid \\
& $\mathrm{I}_{2}$ & 0,195 & 0,504 & Valid \\
& $\mathrm{I}_{3}$ & 0,195 & 0,540 & Valid \\
& $\mathrm{I}_{4}$ & 0,195 & 0,593 & Valid \\
& $\mathrm{I}_{5}$ & 0,195 & 0,533 & Valid \\
\hline \multirow{5}{*}{ Desire } & $\mathrm{D}_{1}$ & 0,195 & 0,702 & Valid \\
& $\mathrm{D}_{2}$ & 0,195 & 0,770 & Valid \\
& $\mathrm{D}_{3}$ & 0,195 & 0,746 & Valid \\
& $\mathrm{D}_{4}$ & 0,195 & 0,694 & Valid \\
& $\mathrm{D}_{5}$ & 0,195 & 0,476 & Valid \\
\hline \multirow{5}{*}{ Action } & $\mathrm{AC}_{1}$ & 0,195 & 0,767 & Valid \\
& $\mathrm{AC}_{2}$ & 0,195 & 0,724 & Valid \\
& $\mathrm{AC}_{3}$ & 0,195 & 0,558 & Valid \\
& $\mathrm{AC}_{4}$ & 0,195 & 0,688 & Valid \\
& $\mathrm{AC}_{5}$ & 0,195 & 0,675 & Valid \\
\hline & $\mathrm{M}_{1}$ & 0,195 & 0,716 & Valid \\
& $\mathrm{M}_{2}$ & 0,195 & 0,687 & Valid \\
& $\mathrm{M}_{3}$ & 0,195 & 0,752 & Valid \\
\hline \multirow{5}{*}{ Binat } & & & &
\end{tabular}

Pada Tabel 2 masing-masing item pertanyaan pada setiap variabel mempunyai $\mathrm{R}_{\text {hitung }}>\mathrm{R}_{\text {tabel }}$ yang berarti semua item pertanyaan dapat dinyatakan valid.
Semua pernyataan kuisioner penelitian dikatakan reliabel, dikarenakan nilai Cronchach's Alpha lebih besar 0,6 yaitu 0,928 .

\section{Analisis Regresi Linear Berganda}

Pengujian regresi linear berganda bertujuan untuk mengukur seberapa besar pengaruh faktor Attention $\left(\mathrm{X}_{1}\right)$, Interest $\left(\mathrm{X}_{2}\right)$, Desire $\left(\mathrm{X}_{3}\right)$ dan Action $\left(\mathrm{X}_{4}\right)$ terhadap minat beli oleh konsumen $(\mathrm{Y})$. Seperti Tabel 3.

Tabel 3. Hasil Analisis Data Regresi Linear Berganda

\begin{tabular}{lrrr}
\hline \multirow{1}{*}{ Model } & \multicolumn{2}{c}{$\begin{array}{l}\text { Unstandardized } \\
\text { Coefficients }\end{array}$} & $\begin{array}{c}\text { Standardized } \\
\text { Coefficients }\end{array}$ \\
\cline { 2 - 4 } & \multicolumn{1}{c}{$\mathrm{B}$} & $\begin{array}{c}\text { Std. } \\
\text { Error }\end{array}$ & Beta \\
(Constant) & -.086 & .998 & \\
Attention $\left(\mathrm{X}_{1}\right)$ & .212 & .061 & .310 \\
Interest $\left(\mathrm{X}_{2}\right)$ & .091 & .057 & .136 \\
Desire $\left(\mathrm{X}_{3}\right)$ & .104 & .068 & .168 \\
& & &
\end{tabular}

Berdasarkan hasil uji pengolahan data Tabel 3 diatas, maka dapat diperoleh persamaan regresi linier berganda sebagai berikut:

$$
\begin{gathered}
\mathrm{Y}=-0,086+0,212 \mathrm{X}_{1}+0,091 \mathrm{X}_{2}+ \\
0,104 \mathrm{X}_{3}+0,191 \mathrm{X}_{4}
\end{gathered}
$$

Berdasarkan persamaan linier berganda di atas dapat diuraikan sebagai berikut:

a. Nilai konstanta $(-0.086)$

Konstanta sebesar $\quad-0.086$ menunjukkan bahwa jika faktor Attention $\left(\mathrm{X}_{1}\right)$, Interest $\left(\mathrm{X}_{2}\right)$, Desire $\left(\mathrm{X}_{3}\right)$ dan Action $\left(\mathrm{X}_{4}\right)$ bernilai 0, maka minat beli konsumen akan mengalami penurunan. 
b. Koefisien regresi faktor Attention $(0,212)$

Nilai positif menunjukkan adanya hubungan searah yang saling mendukung antara variabel attention $\left(\mathrm{X}_{1}\right)$ terhadap minat beli konsumen (Y). Artinya kualitas visual, keunikan dan kejujuran postingan Roti Bund dapat merebut perhatian konsumen, maka akan berpengaruh pula pada minat beli konsumen. Dilihat dari sisi elastisitasnya maka dapat di interpretasikan bahwa kenaikan kenaikan variabel attention akan diikuti dengan kenaikan minat beli konsumen sebesar $21 \%$.

c. Koefisien regresi faktor Interest $(0,091)$

Koefisien regresi pada variabel interest / ketertarikan memiliki pengaruh positif terhadap minat beli konsumen, apabila konsumen tidak merasa terganggu dengan adanya postingan Roti Bund yang berada di timeline dan menganggap caption Roti Bund mudah dipahami maka minat beli konsumen pun ikut berubah. Dilihat dari sisi elastisitasnya maka dapat di interpretasikan bahwa kenaikan kenaikan variabel interest akan diikuti dengan kenaikan minat beli konsumen sebesar $9 \%$. d. Koefisien regresi variabel Desire $(0,104)$

Koefisien regresi linier pada variabel desire / keinginan menunjukkan nilai positif, dimana terdapat hubungan searah antara variabel desire terhadap variabel minat beli konsumen, apabila respon konsumen yang telah melihat caption, testimoni pengguna dan diskon baik maka akan berpengaruh juga terhadap minat beli konsumen. Dilihat dari sisi elastisitasnya maka dapat di interpretasikan bahwa kenaikan kenaikan variabel desire akan diikuti dengan kenaikan minat beli konsumen sebesar $10 \%$.

d. Koefisien regresi variabel Action $(0,191)$

Koefisien regresi linier pada variabel action / tindakan menunjukkan nilai positif yang saling mendukung antara variabel action terhadap variabel minat beli konsumen, minat beli konsumen berubah seiring dengan perubahan respon konsumen yang telah melihat visualisasi foto dan caption Roti Bund. Dilihat dari sisi elastisitasnya maka dapat di interpretasikan bahwa kenaikan kenaikan variabel action akan diikuti dengan kenaikan minat beli konsumen sebesar $19 \%$. 


\section{Analisis Uji t}

Uji t digunakan untuk menguji ada atau tidaknya pengaruh variabel Attention $\left(\mathrm{X}_{1}\right)$, Interest $\left(\mathrm{X}_{2}\right)$, Desire $\left(\mathrm{X}_{3}\right)$ dan Action $\left(\mathrm{X}_{4}\right)$ terhadap minat beli konsumen (Y). Dilakukan dengan menggunakan perbandingan nilai $t_{\text {hitung }}$ dengan $t_{\text {tabel }}$, apabila $t_{\text {hitung }}>t_{\text {tabel }}$ maka ada pengaruh signifikan, dan apabila $\mathrm{t}_{\text {hitung }}<\mathrm{t}_{\text {tabel }}$ maka tidak ada pengaruh signifikan.

a. Pengaruh variabel Attention terhadap minat beli konsumen. Pada taraf signifikan 0,05 diperoleh $t_{\text {hitung }}$ sebesar $3.485>t_{\text {tabel }} 1.988$ maka Ha diterima. Disimpulkan bahwa ada pengaruh yang signifikan antara faktor attention $\left(\mathrm{X}_{1}\right)$ terhadap minat beli konsumen.

b. Pengaruh variabel interest terhadap minat beli konsumen. Pada taraf signifikan 0,05 diperoleh $t_{\text {hitung }}$ sebesar $1.617>\mathrm{t}_{\text {tabel }} 1.988$ maka Ha diterima. Disimpulkan bahwa ada pengaruh yang signifikan antara variabel interest $\left(\mathrm{X}_{2}\right)$ terhadap minat beli konsumen.

c. Pengaruh variabel desire terhadap minat beli konsumen. Pada taraf signifikan 0,05 diperoleh $t_{\text {hitung }}$ sebesar $1.520>\mathrm{t}_{\text {tabel }} 1.988$ maka Ha diterima. Disimpulkan bahwa ada pengaruh yang signifikan antara variabel desire $\left(\mathrm{X}_{3}\right)$ terhadap minat beli konsumen

d. Pengaruh variabel action terhadap minat beli konsumen. Pada taraf signifikan 0,05 diperoleh $t_{\text {hitung }}$ sebesar 2.544> $\mathrm{t}_{\text {tabel }} 1.988$ maka Ha diterima. Disimpulkan bahwa ada pengaruh yang signifikan antara variabel action $\left(\mathrm{X}_{4}\right)$ terhadap minat beli konsumen.

Dari pengujian di atas, dapat disimpulkan bahwa masing-masing variabel berpengaruh terhadap minat beli konsumen. Variabel yang paling berpengaruh adalah variabel attention, dapat dilihat dari hasil $t_{\text {hitung }}(3.485)$ atau koefisien regresi (0.212) variabel attention lebih besar dibandingkan dengan $t_{\text {hitung }}$ atau koefisien regresi variabel lainnya.

\section{Analisis Uji f}

Uji F dilakukan untuk menguji secara bersama-sama apakah variabel attention, variabel interest, variabel desire dan variabel action secara bersama-sama mempunyai pengaruh yang signifikan terhadap minat beli konsumen. Dengan menggunakan $\alpha 5 \%$ dan tingkat keyakinan sebesar 95\% maka besarnya $F_{\text {tabel }}$ adalah 5,49. Hasil menunjukan sebagai tabel berikut. 
Tabel 4. Hasil Uji F

\begin{tabular}{lrlll}
\hline \multicolumn{1}{c}{ Model } & $\begin{array}{c}\text { Sum of } \\
\text { Squares }\end{array}$ & $\begin{array}{c}\text { Mean } \\
\text { Square }\end{array}$ & F & Sig. \\
\hline Regression & 230.345 & 57.586 & 37.518 & $.0001^{\mathrm{b}}$ \\
Residual & 145.815 & 1.535 & & \\
Total & 376.160 & & & \\
\hline
\end{tabular}

Hasil pengolahan data yang telah dilakukan diketahui $\mathrm{F}$ hitung sebesar 37.518. Disimpulkan bahwa faktor attention, interest, desire dan action secara bersama-sama berpengaruh signifikan terhadap minat beli konsumen terhadap instagram Roti Bund.

\section{Uji Determinasi (R square)}

Uji ini dilakukan untuk menentukan persentase total variasi dalam variabel dependen yang diterangkan oleh variabel independen secara bersama-sama, dan untuk mengetahui seberapa besar pengaruh variabel independen terhadap variabel dependen. Nilai determinasi ditentukan dengan nilai Adjusted $R$ square.

Tabel 5. Hasil Uji Determinasi

\begin{tabular}{ccccc}
\hline Model & $\mathrm{R}$ & $\begin{array}{c}\mathrm{R} \\
\text { Square }\end{array}$ & $\begin{array}{c}\text { Adjusted } \\
\text { R Square }\end{array}$ & $\begin{array}{c}\text { Std. Error } \\
\text { of the } \\
\text { Estimate }\end{array}$ \\
\hline 1. & $.783^{\mathrm{a}}$ & .612 & .596 & 1.239 \\
\hline
\end{tabular}

Hasil perhitungan $\mathrm{R}$ square dan dilihat dari koefisien determinasi yang disesuaikan (adjusted $R$ square) sebesar 0,596 . Hal ini berarti $59,6 \%$ minat beli konsumen dipengaruhi oleh faktor Attention $\left(\mathrm{X}_{1}\right)$, Interest $\left(\mathrm{X}_{2}\right)$, Desire $\left(\mathrm{X}_{3}\right)$ dan Action $\left(\mathrm{X}_{4}\right)$. Sedangkan sisanya sebesar 40,4\% dipengaruhi oleh faktor lain yang tidak dijelaskan dalam penelitian ini.

Hubungan antara faktor Attention $\left(\mathrm{X}_{1}\right)$, Interest $\left(\mathrm{X}_{2}\right)$, Desire $\left(\mathrm{X}_{3}\right)$ dan Action $\left(\mathrm{X}_{4}\right)$ dengan minat beli konsumen (Y) didapat nilai $\mathrm{R}$ hitung sebesar 0,783. Dilihat dari tingkat korelasi, nilai korelasi sebesar 0,783. Hal ini berarti hubungan yang dimiliki antara Attention $\left(\mathrm{X}_{1}\right)$, Interest $\left(\mathrm{X}_{2}\right)$, Desire $\left(\mathrm{X}_{3}\right)$ dan Action $\left(\mathrm{X}_{4}\right)$ dengan minat beli konsumen (Y) cukup kuat.

\section{Interprestasi Hasil}

Berdasarkan hasil analisis regresi berganda yang dilakukan, diketahui bahwa variabel attention (perhatian), interest (ketertarikan), desire (keinginan) dan action (tindakan) berhubungan searah dengan minat beli konsumen. Hal ini berarti setiap konsumen melihat Instagram Roti Bund, preferensi konsumen untuk membeli produk produk roti bund akan meningkat, terjadi kenaikan faktor perhatian, ketertarikan, keinginan, dan tindakan setelah melihat instagram Roti bund. Oleh karena itu, untuk berhasil dalam usahanya perusahaan perlu memahami bagaimana konsumen memilih, membeli, menggunakan serta memanfaatkan 
barang dan jasa untuk memuaskan kebutuhan dan keinginan mereka. Dengan demikian perusahaan akan tahu bagaimana membuat instagram yang efektif.

Berdasarkan hasil uji $t$ yang dilakukan dapat diketahui bahwa variabel attention berpengaruh paling dominan terhadap peningkatan minat beli konsumen. Maka diharapkan perusahaan lebih cermat dalam penentuan foto dan caption produknya agar konsumen berkeinginan untuk memperhatikan postingan dan mencari tahu lebih dalam.

Berdasarkan hasil uji $f$ yang dilakukan diketahui bahwa faktor attention, interest, desire dan action secara bersama-sama berpengaruh terhadap minat beli konsumen terhadap instagram Roti Bund.

Hasil perhitungan $\mathrm{R}$ square dan koefisien determinasi yang disesuaikan (adjusted $R \quad$ square) sebesar 0.596 disimpulkan bahwa 59,6\% minat beli konsumen dikarenakan faktor attention, interest, desire dan action. Sedangkan sisanya sebesar $40,4 \%$ dipengaruhi faktor lain yang tidak dijelaskan dalam penelitian ini.

Berdasarkan hasil kuisioner yang telah disebarkan dan hasil pengolahan data, dapat disimpulkan bahwa variabel attention berpengaruh paling dominan terhadap peningkatan minat beli konsumen jadi pada penggunaan instagram yang harus dioptimalkan adalah pada variabel attention terlebih dahulu yaitu adalah postingan produk yang diposting harus menggunakan visualisasi yang berkualitas, jujur dan bisa diandalkan dalam penggunaan gambar dan pada caption harus memiliki keunikan yang membedakan postingan roti bund dengan postingan perusahaan lain. Dalam variabel interest, pada caption harus dijelaskan mengenai keunggulan produk yang bertujuan untuk membuat konsumen tertarik untuk membeli produk tersebut, dan caption pada postingan Roti Bund harus mudah dipahami dan menjawab permasalahan calon konsumen. Dalam variabel desire, harus dijelaskan lebih mendalam mengenai keunggulan produk, pada caption memberikan alasan mengapa harus membeli produk Roti Bund, menyampaikan testimoni pengguna yang telah memberi produk untuk meyakinkan calon konsumen dan memberikan potongan harga pada beberapa produk. Dalam variabel action, Menurut (Zimmerman, n.d.), strategi menggunakan Instagram sebagai media marketing salah satunya adalah pada 
caption postingan memanfaatkan call-toaction, yaitu suatu kalimat ajakan.

\section{KESIMPULAN DAN SARAN}

\section{Kesimpulan}

Faktor attention, interest, desire dan action secara bersama-sama berpengaruh signifikan terhadap minat beli konsumen terhadap instagram Roti Bund. 59,6\% minat beli konsumen benarbenar dikarenakan faktor attention, interest, desire dan action, sedangkan sisanya sebesar $40,4 \%$ dipengaruhi oleh faktor lain yang tidak dijelaskan dalam penelitian ini. Berdasarkan hasil kuisioner yang telah disebarkan, dapat disimpulkan bahwa variabel attention berpengaruh paling dominan terhadap peningkatan minat beli konsumen jadi pada penggunaan instagram yang harus dioptimalkan adalah pada variabel attention .

\section{Saran}

Saran dalam penelitan selanjutnya adalah untuk menambahkan variabel lain.

\section{DAFTAR PUSTAKA}

Djarwanto, P. ., \& Pangestu, S. (1998). Statistik Induktif (1st ed.). BPFE.

Kementrian Perindustrian. (2019). Industri Pengolahan Kopi Semakin Prospektif.

Nugroho, B. A. (2005). Strategi jitu memilih metode statistik penelitian dengan SPSS. Andi.

Purwidiantoro, M. H., Kristanto, D. F., \& Hadi, W. (2016). Pengaruh Penggunaan Media Sosial Terhadap Usaha Kecil Menengah (UKM). AMIK Cipta Darma Surakarta, $1(1), 30-39$.

Sugiyono. (2010). Metode Penelitian Pendidikan Pendekatan Kuantitatif, kualitatif, dan R\&D. ALFABETA.

Sugiyono. (2012). Memahami Penelitian Kualitatif. PT Alfabet.

Sugiyono. (2016). Metode Penelitian Kuantitatif, Kualitatif dan R\&D. PT Alfabet.

Zimmerman, J. $\quad$ (n.d.). Tony_Silvia,_Terry_Anzur_Power Performance_Multimedia_Storytel ling_for_Journalism_and_Public_R elations_2011.pdf. 